Abstracted/indexed in Academic Search Complete, Asia Journals Online, Bangladesh Journals Online, Biological Abstracts, BIOSIS Previews, CAB Abstracts, Current Abstracts, Directory of Open Access Journals, EMBASE/Excerpta Medica, Google Scholar, HINARI (WHO), International Pharmaceutical Abstracts, Open J-gate, Science Citation Index Expanded, SCOPUS and Social Sciences Citation Index;

ISSN: $1991-0088$

\title{
Effect of water hyacinth root extract on arsenic level in different organs of arsenic-treated rat
}

\section{Shaheen Lipika Quayum}

Department of Pharmacology, Bangabnadhu Sheikh Mujib Medical University, Dhaka, Bangladesh.

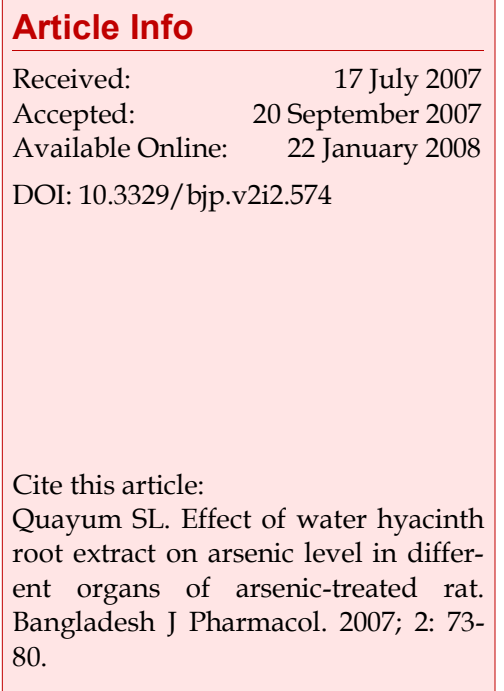

\section{Abstract}

The present study investigated whether the administration of the ethanol extract of water hyacinth (Eichhornia crassipes) ameliorates arsenic from arsenic-treated rats. To induce arsenic accumulation in different organs, arsenic trioxide was administered orally by gavage at a dose of $500 \mu \mathrm{g} / \mathrm{rat} /$ day for 7 days. In search of an effective therapeutic agent to counteract arsenic accumulation and arsenic-induced oxidative stress, different concentrations of ethanol extract of root of water hyacinth $(100,75,50$, and $25 \%$ ) were administered by intraperitoneal injection for last two days which significantly reduced the arsenic accumulation in liver, spleen, kidney, intestine, lungs and skin. Besides, it reduced the oxidative stress caused by arsenic, which was evident by decreased levels of malondialdehyde (MDA) in the above organs. Treatment with either extract $50 \%$ or with a-tocopherol was applied singly and in combination to find out result for comparison of effectiveness on arsenic removal. But the reduction of arsenic and MDA was not dose dependent and not parallel. Water hyacinth, at the dose of $50 \%$ extract was observed to be most effective.

\section{Introduction}

At present more than 40,000 Bangladeshi people are suffering from arsenicosis (Dey et al., 2007). But still there is no specific treatment. Some investigators suggest the effectiveness of retinol, $\beta$-carotene (Chung et al., 2006), zinc (Valko et al., 2005), ascorbic acid (Saha, 2006), selenium (Spallholz et al., 2003), tocopherol (Ramanathan et al., 2003), and spirulina (Misbahuddin et al., 2006). Most of these are anti-oxidants. Combination of vitamins $\mathrm{A}, \mathrm{E}$ and $\mathrm{C}$ were used to treat the cases of chronic arsenic poisoning (Ahmad et al., 1998). The use of several anti-oxidants at a time needs rationality. Duration of treatment of selenium is 12 months (Momin et al., 2007), and for spirulina and zinc 4 months (Misbahuddin et al., 2006). Long duration of treatment may affect the compliance of the patient. Besides, long term uses of drugs may have adverse effect. Selenium may cause impaired endocrine function, hepatotoxicity and dermatological effect (Vinceti et al., 2001). Spirulina produces bad odor (Misbahuddin et al., 2006).

The whole plant of water hyacinth (Eichhornia crassipes) 500-600 g in 10 liters of water removes arsenic $400 \mathrm{mg} /$ L of arsenic completely within 3-6 hours following placement in a bucket, fibrous roots removed $81 \%$ of the arsenic; the leaves and leaf stalks removed none of the arsenic. The mechanism by which water hyacinth removed arsenic from water was by adsorption (Misbahuddin et al., 2002). More than 93\% of arsenite and $95 \%$ of arsenate was removed from a solution containing arsenic $200 \mu \mathrm{g} / \mathrm{L}$ within $60 \mathrm{~min}$ of exposure to the powder of non-living dried root of water hyacinth. The concentration of arsenic remaining in 
solution was less than WHO guideline value of $10 \mu \mathrm{g} / \mathrm{L}$ (Rmalli et al., 2005).

In these circumstances, many researchers try to find out the curative treatment of arsenic poisoning in short duration. Whether the drug from herbal or from other sources could be effective and cheaper without any serious side effects and a great benefit could be obtained for the mankind. Water hyacinth is one such herbal product. Water hyacinth is a rich source of protein content and other nutritional values and has chelating effect. It grows locally in the pond of Bangladesh and free of cost. It is established that the root of water hyacinth remove arsenic from arsenic contaminated water (Misbahuddin et al., 2002). Therefore, the present study has been designed to find out whether extract of the root of water hyacinth can remove arsenic from different organs of arsenic-treated rat.

\section{Materials and Methods}

\section{Chemicals}

Arsenic trioxide $\left(\mathrm{As}_{2} \mathrm{O}_{3}\right)$, silver diethyldithiocarbamate (SDDC), hexamethylen-tetramine and other reagents for arsenic estimation were purchased from E. Merck (Germany). Thiobarbituric acid and bovine serum albumin were purchased from Sigma-Aldrich Chemie (USA).

\section{Collection of dried roots of water hyacinth}

Fifteen kilogram roots of water hyacinth were obtained from the local pond. The roots were cleaned, washed and dried in the air at room temperature. After drying, the roots were chopped and then crushed by blender machine.

\section{Ethanol extract of root of water hyacinth}

The dried $2 \mathrm{~kg}$ roots of water hyacinth after crushing was soaked in 5 liters of $80 \%$ ethanol (ethanol: deionized water; 4:1) in a clean amber colored glass container for 24 hours. After 24 hours, it was filtered. The filtrate was condensed by rotatory vacuum evaporator (Buchi Rotavapor R-114, Switzerland) at $40^{\circ} \mathrm{C}$ and $60-70$ revolutions per min. Total $305 \mathrm{~mL}$ of yellowishgreen colored extract was obtained and preserved in an amber colored bottle at $-20^{\circ} \mathrm{C}$.

\section{Dilution of ethanol extract}

Ethanol extract of water hyacinth root 75, 50 and 25\% solutions were prepared by dissolving 75, 50 and $25 \mathrm{~mL}$ of water hyacinth extract concentrate in 25, 50 and 75 $\mathrm{mL}$ of deionized distilled water. Undiluted extract was considered as $100 \%$ solution. All the samples were preserved in amber color bottles at $-20^{\circ} \mathrm{C}$ before use.

\section{Procedure}

Rats were randomly divided into 6 groups to observe the effect of different concentrations of water hyacinth extract on arsenic removal. All the rats received normal diet and water ad libitum with or without arsenic (500 $\mu \mathrm{g} /$ day) through gavage for 7 days. Different concentrations of water hyacinth root extract were administered by intraperitoneal injection on day 6 and 7 . In some experiments, a-tocopherol (3.5 mg/rat/day) was administered through gavage.

\section{Sacrifice of animals, collection and preservation of organs}

The rats of all groups were sacrificed on day 8. Sacrifice procedure was performed under light chloroform anesthesia in between 9-10 AM. Rats were kept fasting overnight the day before sacrifice. The abdomen of each rat was opened by midline incision and extended to open the thorax. Then the liver, spleen, kidneys, intestine, and lungs were dissected out and skin was isolated. These organs were packed in separate polyethylene packets with accurately labeled and preserved at $-20^{\circ} \mathrm{C}$ until analysis.

\section{Preparation of tissue homogenate}

At first the tissue was taken in a petri dish containing Tyrode's solution at $0-4^{\circ} \mathrm{C}$ (resting in an ice bath). Tissue was cleaned properly, chopped into small pieces and homogenized in a hand tissue homogenizer with 4 $\mathrm{mL}$ Tyrode's solution by keeping the homogenizer in the ice bath.

\section{Estimation of tissue arsenic level (SDDC method; Bauer, 1982)}

Inorganic arsenic was reduced to arsine $\left(\mathrm{AsH}_{3}\right)$ by zinc in strong acid solution in an arsine generator. The arsine was then passed through a scrubber containing cotton wool moistened with lead acetate and into an absorber tube containing SDDC (silver diethyldithio carbamate) dissolved in chloroform. The arsine reacted with the silver salt, forming a soluble red color complex whose absorbance was read in a spectrophotometer (UV-VIS Spectophotometer-1201, Shimadzu, Japan). The maximum absorbance of the resulting color complex is at $525 \mathrm{~nm}$. It has two steps: Acid digestion and arsine generation.

$\mathrm{Zn}+\mathrm{As}_{2} \mathrm{O}_{3}+\mathrm{HCl}{ }^{\circledR} \mathrm{AsH}_{3}+\mathrm{ZnCl}_{2}+\mathrm{H}_{2} \mathrm{O}$

\section{Acid digestion}

From the particular organ the tissues were cleaned 
properly from fascia and clotted blood with Tyrode's solution in a petri dish keeping it on the ice bath. It was carefully weighed of $300 \mathrm{mg}$ spleen and $500 \mathrm{mg}$ in case of other five tissues and was taken in $100 \mathrm{~mL}$ conical flasks. In each conical flask $2 \mathrm{~mL}$ concentrated sulfuric acid, $3 \mathrm{~mL}$ concentrated nitric acid and $2 \mathrm{~mL}$ concentrated perchloric acid were added. But in case of blank and standard, no tissues were added, instead of tissue in standard $20 \mu \mathrm{L}$ of prepared arsenic stock solution of which contain $20 \mu \mathrm{g}$ of arsenic was added. The flasks were allowed to stand for $10 \mathrm{~min}$ then gentle heat was applied on the digestion plant. As the reaction subsided the heat was increased and kept on the flame till the contents of the flask became colorless. Then the flame was turned off and the flasks were allowed to cool. When the digestion was completed all the carbonaceous material should had been destroyed, resulting in a solution of heavy metals in acid. The color of the flask became yellowish-brown.

\section{Arsine generation}

After digestion of the tissue with strong acids, the trivalent arsenic was treated with zinc and hydrochloric acid to liberate arsine gas, which was chelated by SDDC. The whole process took place in an airtight glass apparatus named arsine generator. It has two detachable parts-generation part and scrubber with absorber part. After cooling the flasks, the digest contents were transferred to the clean and dry $250 \mathrm{~mL}$ conical flasks. The contents were diluted with deionized distilled water and $3 \mathrm{~mL}$ of concentrated hydrochloric acid was added to make the volume of $35 \mathrm{~mL}$. To each flask 50 $\mu \mathrm{L}$ potassium iodide was added. After some time 100$200 \mu \mathrm{L}$ stannous chloride was added to each flask drop by drop till the contents of the flask became clear. Plugs of cotton wool wetted with a few drops of $10 \%$ lead acetate that were inserted in the scrubber part of the arsine generator assembly. Three milliliter of SDDC was taken in each absorber part of arsine generator and $3 \mathrm{~g}$ zinc pellets were added to each flask. Then, immediately absorber part was joined tightly to generator flask. Within minutes, reaction begun and bubbling was observed as arsine gas was generated. The reaction was allowed to continue for $30 \mathrm{~min}$. After 30 minutes each sample was transferred in a clean test tube and used for colorimetric measurement of arsenic. The color reagent was transferred to a glass cuvette and the absorbance was measured at $525 \mathrm{~nm}$ in spectrophotometer against blank.

\section{Lipid peroxidation assay}

Lipid peroxidation was estimated using the thiobarbituric acid method to determine the level of MDA, which serves as the index of lipid peroxidation (Hagen et al., 1999). One milliliter of tissue homogenate was taken in a test tube and reacted with $4.5 \mathrm{~mL}$ of $5.5 \%$ TCA. The mixture was vortexed (Vortex mixer- 2000, Digisystem Laboratory, Taiwan) and centrifuged at $1,725 \times \mathrm{g}$ for 10 min. The supernatent was poured into another test tube; $1 \mathrm{~mL}$ of $0.7 \%$ thiobarbituric acid was added to it. The mixture was kept in a boiling water bath $\left(100^{\circ} \mathrm{C}\right)$ for $10 \mathrm{~min}$, forming a pink color solution. The mixture was then cooled immediately and the absorbance was measured at $532 \mathrm{~nm}$ by spectrophotometer. Lipid peroxidation was calculated using a molar extinction coefficient for MDA of $1.56 \times 10^{5} \mathrm{~mol} / \mathrm{L}$.

\section{Total protein estimation}

The protein content of tissue homogenate used for the study was estimated by Lowry's method (Lowry et al., 1951). Test tubes were cleaned, properly air dried and labeled as blank, standard and samples. Two $\mathrm{mL}$ of the solution (sodium carbonate $2 \%$ : sodium potassium tartrate $1 \%$ : copper sulfate $0.5 \% ; 48: 1: 1$ ) was taken to each test tube. After that $25 \mu \mathrm{L}$ of the sample (tissue homogenate) and $15 \mu \mathrm{L}$ of physiological solution to the labeled test tube for sample, $40 \mu \mathrm{L}$ physiological solution to blank labeled test tube, and $40 \mu \mathrm{L}(160 \mu \mathrm{g})$ of BSA was added to the standard labeled test tube. They were vortexed and preincubated at room temperature for $10 \mathrm{~min}$. Then $200 \mu \mathrm{L}$ of dilute folin phenol solution was added to each test tube and immediately vortexed. The test tubes were incubated at room temperature for $30 \mathrm{~min}$. Absorbance of each sample was then determined at $600 \mathrm{~nm}$ wavelength by spectrophotometer.

\section{Data collection and statistical analysis}

Statistical analysis was done by SPSS software, Version 10.0, USA. The quantitative variables were expressed as mean \pm SD. ANOVA (multiple comparisons) was done for statistical analysis. Post hoc analysis of differences were done by unpaired ' $t$ ' test.

\section{Results}

The concentration of arsenic in liver, spleen, kidneys, intestine, lungs and skin were estimated both in the presence or absence of arsenic and ethanol extract of water hyacinth. Arsenic level (mean \pm SD) of control rat was $3.5 \pm 0.6 \mu \mathrm{g} / \mathrm{g}$ of tissue in liver. But it increased to $26.8 \pm 2.7 \mu \mathrm{g} / \mathrm{g}$ of tissue when rats were treated with arsenic $500 \mu \mathrm{g} /$ day for 7 days (Table I). That is, there was about 8-fold increase in arsenic accumulation and was statistically significant $(p<0.001)$. Treatment with different concentrations $(100,75,50,25 \%)$ of water 


\section{Table I}

Effect of different concentrations of water hyacinth extract on arsenic and malondialdehyde level in rat liver

\begin{tabular}{|c|c|c|c|c|}
\hline \multirow[t]{2}{*}{ Treatment $(\mathrm{n}=6)$} & \multicolumn{2}{|c|}{ Arsenic } & \multicolumn{2}{|c|}{ Malondialdehyde } \\
\hline & $\begin{array}{c}\text { Concentration in } \mu \mathrm{g} / \mathrm{g} \\
(\text { mean } \pm \mathrm{SD})\end{array}$ & \%Reduction & $\begin{array}{l}\text { Concentration in } \mathrm{nmol} / \mathrm{mg} \\
(\text { mean } \pm \mathrm{SD})\end{array}$ & \%Reduction \\
\hline $\mathrm{C}$ & $3.5 \pm 0.6$ & & $3.4 \pm 0.6$ & \\
\hline A & $26.8 \pm 2.7 \mathrm{a}$ & & $12.1 \pm 1.6^{\mathrm{f}}$ & \\
\hline A.E 100 & $10.4 \pm 1.2^{\mathrm{ab}}$ & 60.8 & $9.9 \pm 1.3^{\mathrm{fg}}$ & 16.5 \\
\hline A.E 75 & $10.9 \pm 1.5^{\mathrm{ab}}$ & 58.8 & $9.3 \pm 0.9 \mathrm{fg}$ & 22.1 \\
\hline A.E 50 & $8.9 \pm 1.4^{\mathrm{abd}}$ & 66.0 & $8.7 \pm 0.7 \mathrm{fgh}$ & 27.2 \\
\hline A.E 25 & $16.1 \pm 2.4^{\text {abcde }}$ & 38.9 & $10.4 \pm 0.9 \mathrm{fgi}$ & 13.3 \\
\hline
\end{tabular}

Treatments: $\mathrm{C}=$ Control, $\mathrm{A}=$ Arsenic, A.E $100=$ Arsenic plus extract $100 \%$, A.E $75=$ Arsenic plus extract $75 \%$, A.E $50=$ Arsenic plus extract $50 \%$, A.E $25=$ Arsenic plus extract $25 \%$. Concentration of arsenic: aSignificant difference C vs A, A.E 100, A.E 75 , A.E 50 and A.E 25 at P<0.001; bA vs A.E 100 , A.E 75, A.E 50 and A.E 25 at P<0.001; 'A.E 100 vs A.E 25 at P<0.001; dA.E 75 vs A.E 25 at P<0.001; eA.E 50 vs A.E 25 at P<0.001; and no significant difference A.E 100 vs A.E 75 and A.E 50, and A.E 75 vs A.E 50. Concentration of malondialdehyde: fSignificant difference C vs A, A.E 100, A.E 75 , A.E 50 and A.E 25 at $\mathrm{P}<0.001 ; \mathrm{gA}$ vs A.E 100, A.E 75, A.E 50 and A.E 25 at $\mathrm{P}<0.01, \mathrm{P}<0.001, \mathrm{P}<0.001$ and $\mathrm{P}<0.01$ respectively; hA.E 100 vs A.E 50 at $\mathrm{P}<0.05$; iA.E 50 vs A.E 25 at P<0.001; and no significant difference A.E 100 vs A.E 75 and 25, A.E 75 vs A.E 50, and A.E 75 vs A.E 25

Table II

\section{Effect of a-tocopherol and water hyacinth extract administered alone or in combination on arsenic and} malondialdehyde level in rat liver

\begin{tabular}{|lcccc|}
\hline Treatment $(\mathrm{n}=6)$ & \multicolumn{2}{c}{ Arsenic } & Malondialdehyde \\
\cline { 2 - 5 } & $\begin{array}{c}\text { Concentration in } \mu \mathrm{g} / \mathrm{g} \\
(\text { mean } \pm \mathrm{SD})\end{array}$ & \%Reduction & $\begin{array}{c}\text { Concentration in nmol/mg } \\
(\text { mean } \pm \text { SD) }\end{array}$ & \%Reduction \\
\hline A & $23.3 \pm 2.2$ & 53.6 & $12.8 \pm 1.9$ & 40.9 \\
A.E & $10.8 \pm 0.7 \mathrm{a}$ & 74.5 & $7.5 \pm 1.0^{\mathrm{c}}$ & 39.8 \\
A.T & $5.9 \pm 1.5^{\mathrm{ab}}$ & 70.7 & $7.5 \pm 1.1^{\mathrm{c}}$ & 45.6 \\
A.T.E & $6.7 \pm 2.0^{\mathrm{ab}}$ & $6.9 \pm 0.4^{\mathrm{c}}$ & \\
\hline
\end{tabular}

Treatments: $\mathrm{A}=$ Arsenic, A.E $=$ Arsenic plus extract 50\%, A.T = Arsenic plus a-tocopherol, A.T.E = Arsenic plus a-tocopherol plus extract $50 \%$. Concentration of arsenic: aSignificant difference A vs A.E, A.T and A.T.E at $\mathrm{p}<0.001$; ${ }^{\mathrm{b}}$ A.E vs A.T and A.T.E at $\mathrm{p}<0.001$; and no significant difference A.T vs A.T.E. Concentration of malondialdehyde: cSignificant difference A vs A.E, A.T and A.T.E at P<0.001; and no significant difference A.E vs A.T and A.T.E, and A.T vs A.T.E.

Table III

Removal of arsenic from arsenic loaded organs

\begin{tabular}{|c|c|c|c|c|c|}
\hline \multirow[t]{2}{*}{ Treatment } & \multicolumn{5}{|c|}{$\%$ Removal of arsenic from organs } \\
\hline & Intestine & Lungs & Kidneys & Spleen & Skin \\
\hline Arsenic & - & - & - & - & - \\
\hline Arsenic + water hyacinth root extract $100 \%$ & 48.3 & 65.8 & 43.1 & 53.9 & 35.9 \\
\hline Arsenic + water hyacinth root extract $75 \%$ & 55.7 & 64.5 & 34.9 & 43.6 & 52.4 \\
\hline Arsenic + water hyacinth root extract $50 \%$ & 66.8 & 66.6 & 64.9 & 58.2 & 33.2 \\
\hline Arsenic + water hyacinth root extract $25 \%$ & 28.7 & 29.3 & 26.8 & 15.8 & 23.6 \\
\hline
\end{tabular}

hyacinth extract for the last two days produced significant depletion of arsenic than that of arsenictreated group. Maximum reduction was observed in $50 \%$ extract treated group $(66.0 \%)$. The concentration was $8.9 \pm 1.4 \mu \mathrm{g} / \mathrm{g}$ of tissue. No significant difference found among the groups- 50, 75 and $100 \%$ extract treated in arsenic depleting action. Comparing the effect of $50 \%$ water hyacinth extract with a-tocopherol showed that there was more reduction of arsenic by atocopherol alone than by $50 \%$ extract ( 74.5 vs $53.6 \%$ ). 


\begin{tabular}{|c|c|c|c|c|c|}
\hline \multicolumn{6}{|c|}{ Table IV } \\
\hline \multicolumn{6}{|c|}{ Malondialdehyde level in different organs } \\
\hline \multirow[t]{2}{*}{ Groups } & \multicolumn{5}{|c|}{ Malondialdehyde level } \\
\hline & Intestine & Lungs & Kidneys & Spleen & Skin \\
\hline Arsenic & $6.0 \pm 0.6$ & $7.7 \pm 0.9$ & $15.7 \pm 0.8$ & $8.2 \pm 1.4$ & $8.7 \pm 0.5$ \\
\hline Arsenic + water hyacinth root extract $100 \%$ & $4.8 \pm 0.3$ & $6.6 \pm 0.9$ & $11.9 \pm 1.0$ & $6.4 \pm 0.3$ & $6.7 \pm 0.4$ \\
\hline Arsenic + water hyacinth root extract $75 \%$ & $4.4 \pm 0.5$ & $6.6 \pm 0.5$ & $9.9 \pm 1.0$ & $5.8 \pm 0.7$ & $5.9 \pm 0.6$ \\
\hline Arsenic + water hyacinth root extract $50 \%$ & $4.1 \pm 0.6$ & $5.9 \pm 0.6$ & $8.9 \pm 1.0$ & $5.6 \pm 0.9$ & $5.5 \pm 1.0$ \\
\hline Arsenic + water hyacinth root extract $25 \%$ & $4.9 \pm 0.4$ & $7.0 \pm 1.0$ & $12.9 \pm 1.2$ & $6.9 \pm 1.0$ & $7.3 \pm 0.5$ \\
\hline
\end{tabular}

However, no additive effect was observed when both were administered simultaneously (Table II).

The mean amount of arsenic in the intestine, lung kidney, spleen and skin of normal healthy rats were $3.86,3.58,5.47,4.28,3.23 \mu \mathrm{g} / \mathrm{g}$ tissues. That is, kidney showed highest amount of arsenic whereas skin showed lowest amount of arsenic. Treatment of arsenic for 7 days increased the arsenic levels (intestine- 22.5, lung- 13.1, kidney- 20.5, spleen- 26.8 and skin- $9.5 \mu \mathrm{g} / \mathrm{g}$ tissue). Treatment with 100, 75, 50, 25\% ethanol extract for last 2 days decreased the arsenic level significantly (Table III).

In normal healthy rat liver the mean MDA level was 3.4 $\pm 0.6 \mathrm{nmol} / \mathrm{mg}$ protein. But on exposure to arsenic the level increased to $12.1 \pm 1.6 \mathrm{nmol} / \mathrm{mg}$ protein (about 4 times; $\mathrm{p}<0.001$ ). Administration of different concentrations of water hyacinth extract reduced MDA significantly. Maximum reduction $(27.2 \%)$ in extract $50 \%$ which was $8.7 \pm 0.7 \mathrm{nmol} / \mathrm{mg}$ protein. Treatment with $50 \%$ extract, a-tocopherol or both result a significant decrease MDA although the differences among these three groups were not statistically significant. Reduction of arsenic and MDA was not dose-depended and not parallel. More or less similar changes were observed in spleen, kidneys, intestine, lungs and skin (Table IV).

\section{Discussion}

The present study was carried out to investigate whether the active compound of ethanol extract of water hyacinth can combat arsenic poisoning. This work is extremely important in the context of Bangladesh, when arsenic poisoning has been found as the biggest environmental health hazard in the country, in the world and further because there is no specific treatment to confront the hazard. In this study, we found that concentration of arsenic in different tissues of the control rats were low.

Experimentally the rat was arsenic treated by administering arsenic trioxide solution through gavage, $500 \mu \mathrm{g}$ for consecutive seven days. Treatment showed concentration of arsenic increased in different tissues (38 -fold). In arsenic treated group, higher level was in the liver, probably due to high blood supply and toxic amount of arsenic which the liver could not metabolize. The MDA level of the tissues also increased in arsenic treated groups (2-4-fold). During the last two days, different concentrations of ethanol extract of the root of water hyacinth were administered to different groups of rat. Effectiveness of different concentrations of water hyacinth extract was due to enhanced removal of arsenic, as evidenced by decreased concentration of arsenic in six organs as compared with control arsenictreated group. But the removal of arsenic of different concentrations was not the same. Among the different concentrations, 50\% extract-treated group was more effective, $25 \%$ was less effective. Removal of arsenic was not dose dependent and did not increase after increasing the dose beyond $50 \%$. But the water hyacinth extract was not equally effective in the removal of arsenic and MDA in the tissues. In all the tissues, 60$70 \%$ arsenic was removed by $50 \%$ extract, except in the skin.

In another study, 50\% extract and a-tocopherol was compared to see the effectiveness in the removal of arsenic and MDA. a-tocopherol was more effective for the removal of arsenic in intestine and skin. In lung, kidney, liver and spleen, there was no significant difference between $50 \%$ extract and a-tocopherol for removal of arsenic. It was observed that there was no significant difference of $50 \%$ extract and a-tocopherol or both for decreasing the MDA of liver, skin, intestine, spleen and lungs. No additive effect was in simultaneous administration. However, the study also explored the possibility of combined administration of $\alpha$ tocopherol and extract $50 \%$ to achieve better reverse- 
bility of arsenic-induced increase MDA in kidney than individual treatment.

High protein content of water hyacinth may enhance the excretion of arsenic by increasing methylation. Cytokinins are plant hormones that regulate protein synthesis. Methylation is considered the detoxification pathway of inorganic arsenic. The source of methyl groups for arsenic methylation is S-adenosylmethionine. Population thriving on diets low in methionine is likely to suffer more from high arsenic toxicity. Sulfur containing amino acids e.g. methionine, cystine and protein deficiency are considered to decrease the cofactors necessary to synthesize S-adenosylmethionine. Water hyacinth contains methionine (Duke, 1983). From previous works it is well documented that micronutrients and anti-oxidants has significant role in the treatment of chronic arsenic poisoning. Selenium, zinc iron, spirulina (Saha et al., 2005), lipoic acid (Tabassum, 2006), spinach extract (Umar, 2007), ascorbic acid and a-tocopherol all have ameliorating role against chronic arsenic poisoning. Water hyacinth is a rich source of amino acid, micronutrients and antioxidants, which could be a good solution for management of arsenicosis. It contains $\beta$-carotene, amino acid, melatonin, trace element, all of which have anti-oxidant property.

Water hyacinth removes arsenic from arsenic contaminated drinking water (Misbahuddin et al., 2002). But the role of water hyacinth in the removal of arsenic, at the tissue level is not yet established.

It was already evident from previous studies that administering arsenic to rats for different periods induces significant increase in arsenic accumulation (Nasir et al., 2002; Umar, 2007). In this study, emphasis was given on the role of water hyacinth extract to remove arsenic from different organs. It was sought to establish a relationship between tissue arsenic level and lipid peroxidation. In this study, arsenic treatment resulted in a significant increase in lipid peroxidation in all the organs. Oxidative stress due to enhanced production of free radicals has been demonstrated as one of the several mechanisms involved in arsenicinduced toxic effects in different organs. $\mathrm{O}_{2}$-and $\mathrm{H}_{2} \mathrm{O}_{2}$ injure cells as a result of the generation of a more potent oxidizing species. In addition to $\mathrm{O}_{2}$ and $\mathrm{H}_{2} \mathrm{O}_{2}$, the third essential component of the complex that mediates the lethal cell injury is a cellular source of ferric iron. $\mathrm{O}_{2}-$ reduces a cellular source of ferric to ferrous iron, and the latter then reacts with $\mathrm{H}_{2} \mathrm{O}_{2}$ to produce a more potent oxidizing species, like the $\mathrm{OH}^{-}$or an equivalently reactive species. In turn, $\mathrm{OH}^{-}$initiates the peroxidative decomposition of the phospholipids of cellular membranes. $\mathrm{OH}^{-}$also damages the inner mitochondrial membrane. Upon mitochondrial deenergization, sequence of events is initiated that similarly leads to the loss of viability of the cell (Farber, 1994).

Nandi et al., 2005 showed the ameliorative potential of certain amino acids like cysteine, methionine and vitamins like ascorbic acid and thiamine on oxidative stress. Arsenic exposure resulted in significantly higher accumulation of arsenic in blood, liver and kidney. Similar results were documented in the tissues of this current study. Treatment with vitamins and amino acids resulted in reversal of oxidative stress with decline in tissue arsenic burden. All the treatment produced tissue specific changes in lipid peroxide level, antioxidant enzyme activities and tissue arsenic burden. a-tocopherol and 50\% extract had no additive effect, because water hyacinth may either exert maximum efficacy or both have different mechanism. The mechanism of water hyacinth may be chelation.

\section{Conclusion}

Root of water hyacinth may be effective in the removal of arsenic. However, studies are required to examine the effect on other animals and patients of chronic arsenic poisoning.

\section{Acknowledgement}

I am grateful to Prof. Mir Misbahuddin of Bangabandhu Sheikh Mujib Medical University, Dhaka, for his kind support and encouragement throughout this work.

\section{References}

Ahmad Sk, Faruquee MH, Sayed MHSU, Khan MH, Hadi SA, Khan AW. Chronic arsenic poisoning: Management by vitamins A, E, C regimen. JOPSOM. 1998; 17: 19-26.

Ahsan H, Chen Y, Parvez F, Zablotska L, Argos M, Hussain I, Momotaj H, Levy D, Cheng Z, Slavkovich V, Geen VA, Howe GR, Graziano JH. Arsenic exposure from drinking water and risk of premalignant skin lesions in Bangladesh: Baseline results from the health effects of arsenic longitudinal study. Am J Epidemiol. 2006; 163: 1138-48.

Andrew AS, Karagas MR, Hamilton JW. Decreased DNA repair gene expression among individuals exposed to arsenic 
in United States drinking water. Int J Cancer. 2003; 104: 26368.

Bauer JD. Clinical laboratory methods. $9^{\text {th }}$ ed. St. Louis, MO, Mosby, 1982, pp 664-65.

Chung JS, Haque R, Guha Mazumder DN, Moore LE, Ghosh N, Samanta S, Mitra S, et al. Blood concentration of methionine, selenium, beta-carotene, and other micronutrients in a case-control study of arsenic-induced skin lesions in West Bengal, India. Environ Res. 2006; 101: 230-37.

Dey RK, Islam AZMM, Khandker S, Ahmad SA. Arsenic-safe drinking water and anti-oxidants for the management of arsenicosis patient. In: Applied research on arsenic in Bangladesh. Misbahuddin M (ed). Dhaka, World Health Organization (Bangladesh), Directorate General of Health Services, Government of Bangladesh, 2007, pp 103-16.

Duke JA. Eichornia crassipes (Mart.) Solms. Handbook of Energy Crops (unpublished). 1983; URL: http:// www.hort.purdue.edu. Accessed on 6/4/2007.

Farber LJ. Mechanism of cell injury by activated oxygen species. Environ Health Perspect. 1994; 102: 17-24.

Garcia-Chavex E, Jimenez I, Segura B, Del Razo LM. Lipid oxidative damage and distribution of inorganic arsenic and its metabolites in the rat nervous system after arsenite exposure: Influence of alpha-tocopherol supplementation. Neurotoxicology 2006; 27: 1024-31.

Hagen TM, Ingersoll RT, Lykkesfeldt J, Liu J, Wehr CM, Vinarsky V, Bartholomew JC, Ames BN. (R)-a-lipoic acid supplemented old rats have improved mitochondrial function, decreased oxidative damage and increased metabolic rate. FASEB J. 1999; 13: 411-18.

Heck JK, Gamble MV, Chen Y, Graziano JH, Slavkovich V, Parvez F, Baron JA, Howe GR, Ahsan H. Consumption of folate-related nutrients and metabolism of arsenic in Bangladesh. Am J Clin Nutr. 2007; 85: 1367-74.

Lowry $\mathrm{OH}$, Rosenbrough NJ, Farr AL, Randall RJ. Protein measurement with the folin phenol reagent. J Biol Chem. $1951 ; 265-75$.

Misbahuddin M, Fariduddin A. Water Hyacinth removes arsenic from arsenic-contaminated drinking Water. Arch Environ Health. 2002; 57: 516-18.

Misbahuddin M, Islam AZMM, Khandker S, Mahmud IA, Islam N, Anjumanara. Efficacy of spirulina extract plus zinc in patients of chronic poisoning: A randomized placebocontrolled study. Clin Toxicol. 2006; 44: 135-41.

Mitra SR, Guha Mazumder DN, Basu A, Block G, Haque R, Samanta S, Ghosh N, Smith MMH, Ehrenstein OS, Smith AH. Nutritional factors and susceptibility to arsenic-caused skin lesions in lesions in West Bengal, India. Environ Health Perspect. 2004; 112: 1104-09.
Momin A, Ali SK, Hague MM. Randomized placebo-controlled trial to evaluate the effectiveness of selenium in the treatment of arsenicosis patients. In: Applied research on arsenic in Bangladesh. Misbahuddin M (ed). Dhaka, World Health Organization (Bangladesh), Directorate General of Health Services, Govt. of Bangladesh, 2007, pp 117-30.

Nandi D, Patra RC, Swarup D. Effect of cysteine, methionine, ascorbic acid and thiamine on arsenic-induced oxidative stress and biochemical alterations in rats. Toxicology 2005; 211: 26-35.

Nasir M, Misbahuddin M, Ali SMK. Selenium intervention in reducing arsenic levels in different tissues. In: Bangladesh Environment 2002, Proceedings of the $2^{\text {nd }}$ International Conference on Bangladesh Environment. Ahmed MF, Tanveer SA, Badruzzaman ABM (eds). ICBEN-2002, Dhaka, Bangladesh, 2002, pp 343-52.

Pal S, Chatterjee AK. Protective effect of methionine supplementation on arsenic-induced alteration of glucose homeostasis. Food Chem Toxicol. 2004; 42: 737-42.

Rabbani GH, Saha SK, Akhtar M, Marni F, Mitra AK, Ahmed S, Alauddin M, Bhattacharjee M, Sultana S, Chowdhury AK. Antioxidants in detoxification of arsenic-induced oxidative injury in rabbits: Preliminary results. J Environ Sci Health A Tox Hazard Subst Environ Eng. 2003; 38: 273-87.

Ramanathan K, Balakumar BS, Panneerselvam C. Effects of ascorbic acid and a-tocopherol on arsenic-induced oxidative stress. Hum Exp Toxicol. 2002; 21: 675-80.

Ramanathan K, Shila S, Kumaran S, Panneerselvam C. Protective role of ascorbic acid and a-tocopherol on arsenicinduced microsomal dysfunctions. Hum Exp Toxicol. 2003; 22: $129-36$

Ramos O, Carrizales L, Yanez L, Mejia J, Batres L, Ortiz D, Diazbarriga F. Arsenic increased lipid peroxidation in Rat tissues by a mechanism independent of glutathione levels. Environ Health Perspect. 1995; 103: 85-88.

Rmalli SWA, Harrington CF, Ayub M, Haris PI. A biomaterial based approach for arsenic removal from water. J Environ Monit. 2005; 7: 279-82.

Saha B. Effect of ascorbic acid on reduced glutathione level in arsenic-loaded isolated liver tissues of rat. Bangladesh J Pharmacol. 2006; 1: 68-71.

Saha SK, Misbahuddin M, Khatun R, Mamun MIR. Effects of hexane extracts of spirulina in the removal of arsenic from isolated liver tissues of rat. Mymensingh Med J. 2005; 14: 191 -95 .

Spallholz JE, Boylan LM, Rahman MM. Environmental hypothesis: Is poor dietary selenium intake an underlying factor for arsenicosis and cancer in Bangladesh and West Bengal, India? Sci Total Environ. 2003; 323: 21-32. 
Tabassum NE. Effect of a-lipoic acid on the removal of arsenic from arsenic-loaded isolated liver tissues of rat. Bangladesh J Pharmacol. 2006; 1: 27-32.

Umar BU. Effect of hexane extract of spinach in the removal of arsenic from rat. Bangladesh J Pharmacol. 2007; 2: 27-34.
Valko M, Morris H, Cronin MT. Metals, toxicity and oxidative stress. Curr Med Chem. 2005; 12: 1161-208.

Vinceti M, Wei ET, Malagoli C, Bergomi M, Vivoli G. Adverse health effects of selenium in humans. Rev Environ Health. 2001; 16: 233-51. 